\title{
Words of Power: Reading Shakespeare and the Bible, by Jem Bloomfield
}

Cambridge: Lutterworth, 2016 | viii + I65 pages | ISBN: 978-071 8-894I3-9 (softcover) £20.00

Jem Bloomfield's Words of Power: Reading Shakespeare and the Bible samples the history and use of the Bible and of Shakespeare's collected plays, and explores how this history and use might inform our readings today.

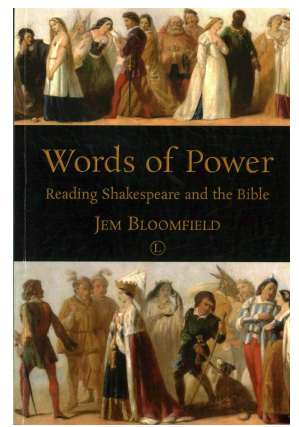
Bloomfield argues that understanding the formation of, interpretative methods for, and our assumptions about either one of these collected texts can map onto and enrich our reading and understanding of the other. More generally, this work challenges readers to hold such texts far enough away "to catch a glimpse of them beyond the distorting lenses of our previous assumptions and experience" (I 54 ), a challenge that is certainly worthwhile.

For Bloomfield, what draws these texts together into easy comparison is their perceived status. That is, Bloomfield starts with the premise that both of these texts can be considered scriptural or sacred texts. Following John

${ }^{3}$ See pp. 7, 35, 77, I 57, 238-39 which together explore this blend of Matthew I 0:29 with Calvin's Institutes, situating it alongside Hamlet Senior's apparent Catholicism and Horatio's scepticism, and — with Anthony B. Dawson—noting the hateful destiny awaiting the disciples despite such reassurances. 
Barton's exploration of scriptural texts, Bloomfield notes that Shakespeare and the Bible have been treated reverentially, received similarly, considered as consistent, and thought to have excess of meaning. In terms of reverence, both texts have been treated as repositories of knowledge and wisdom: each word carries an assumed weight and value not to be passed over lightly. In terms of reception, these repositories have perceived relevance in each generation, being continually applicable. In terms of consistency, both texts have been read with an eye to unity; for example, just as various biblical verses composed in disparate historical periods are retrospectively gathered to affirm a subsequent theological point, Shakespeare's histories have at times been performed together as though they were conceived sequentially and holistically. In terms of excess of meaning, both texts have been read for meaning beyond the literal sense; that is, readers have assumed that layers of meaning exist waiting to be discovered through diverse methods of reading. These four points underpin Bloomfield's main point of exploration: "how both Shakespeare and the Bible are read into the forms with which we are familiar" (I 2).

Accordingly, each chapter draws parallels between Shakespeare's collected plays and the Bible. The first chapter explores the books that are included in each respective canon, demonstrating how both canons were retrospectively codified and how this codification was (and still is) subject to debate. Touching on textual criticism, the second chapter is concerned with the words themselves, recognizing that there is variance among the extant sources and questioning the idea of an ideal text. The third chapter samples diverse methods of interpretation, demonstrating that interpretations can be subjective; nevertheless, each interpretation often claims to access the real meanings behind the texts. The fourth chapter examines how these texts have been silently read or publicly performed and how these methods of reading and performance (and suspicion of these methods at various points in history) suggest underlying assumptions about the meaning of the texts. The fifth chapter looks at how groups or institutions "use Shakespeare and the Bible to validate themselves and their own activities" (I 2 I), such as using the words "Bible" or "Shakespeare" as part of an institution's name to legitimize itself or its ethos. The sixth chapter expands this idea to the words of Shakespearean and biblical texts, providing examples where these texts have been cited and appropriated outside of theatrical and religious contexts respectively.

Bloomfield does well to engage the reader by exploring wide-ranging texts, from Irenaeus to British rapper Akala. For example, Bloomfield reads 
Handel's "Zadok the Priest" relative to its singing at English coronations, demonstrating that the choral anthem at once establishes a sense of legitimacy by connecting the monarchy to King Solomon but yet calls that legitimacy into question when one considers the injunctions of I Samuel 8. Or again, to illustrate how reactions to Shakespearean works can continue to change, Bloomfield examines a speech made in the Upper Chamber in 2000 by Lord McCarthy, who invokes his own changing perceptions towards anti-Semitic characters in The Merchant of Venice and misogyny in The Taming of the Shrew to lobby for the lowering of the age of consent for homosexual sex so that it aligns with the age of consent for heterosexual sex. Through such examples, Bloomfield engagingly challenges readers to reconsider the implications and power of invoking the Bible and Shakespeare through name, allusion, or citation.

As Shakespeare and the Bible are so extensively studied, any work that discusses these two areas will need either to be impossibly long or to acknowledge its necessarily numerous omissions. While Bloomfield frequently acknowledges that his work samples rather than exhaustively explores the field, there are few points at which Words of Power could benefit from being slightly more expansive. For example, when discussing Shakespeare's First Folio in the chapter on the creation of the canons, Bloomfield states that "Printed editions of [Shakespeare's] plays had been in circulation during Shakespeare's life, in the cheap one-volume format called 'quartos' that had a similar place to modern paperbacks" (28) and "The plays had appeared in print before his death, but only in the cheap and perishable editions known as 'quartos' and 'octavos'" (29). At such points, it might be worth stating more clearly that many of Shakespeare's plays were not published until they appeared in the First Folio, such as Macbeth and Measure for Measure, both of which are mentioned in that same chapter. On a larger scale, Words of Power could have contextualized itself within the growing list of articles and books that discuss Shakespeare and the Bible-even if only to differentiate itself from its predecessors. For example, while Words of Power most certainly differs from works that catalogue Shakespeare's biblical references, such as Naseeb Shaheen's (1987-1993), it could perhaps fruitfully acknowledge other scholarship that examines points of intersection between the Shakespearean canon and the Bible or that questions how Shakespeare himself may have used or alluded to the Bible, such as Steven Marx's Shakespeare and the Bible (2000), Shakespeare, the Bible, and the Form of the Book, edited by Travis DeCook and Alan Galey (20I I), or Hannibal Hamlin's The Bible in Shakespeare (2013). 
That is, Words of Power could have more readily moored itself in the widening sea of work on Shakespeare and the Bible. As Words of Power appears to be for non-specialists, this lack of mooring could easily be excused. However, as it does mention or engage several Shakespearean scholars from the past hundred years (e.g. Stephen Greenblatt, Emma Smith, Tiffany Stern, Paul Yachnin, A.C. Bradley, L.C. Knights), the lack of mooring stands out, particularly as this book often looks towards reception.

Words of Power does ask very useful questions of its readers and often provides stimulating examples. It demands that its readers consider how biblical and Shakespearean texts have been variously received and how such reception influences our understanding and use of those texts today.

Michael Cop

University of Otago 